\title{
Analysis and Source Identification of Heavy Metals in Soils of Central Urban Area of Chongqing, China
}

Wende Chen ( $\nabla$ chenwende@mail.cdut.edu.cn )

Chengdu University of Technology

Kun Zhu

Chengdu university of technology https://orcid.org/0000-0003-2871-4155

\section{Yankun Cai}

Chengdu university of technology

\section{Peihao Peng}

Chengdu university of technology

\section{Research Article}

Keywords: Soil heavy metals, Influence Factor, PCA-APCS Receptor Model, Categorical regression analysis, Spatial analysis of hot spots

Posted Date: September 17th, 2021

DOI: https://doi.org/10.21203/rs.3.rs-856871/v2

License: (1) (1) This work is licensed under a Creative Commons Attribution 4.0 International License. Read Full License 


\section{Analysis and Source Identification of Heavy Metals in Soils of Central Urban Area of}

\section{Chongqing, China}

3 Abstract

4 In megacities, due to frequent human activities, large amounts of metals enter the soil indirectly or directly and eventually flow to people through the food chain. Therefore, the analysis and identification of soil heavy metal sources is an important part of revealing soil heavy metal pollution. The spatial content and potential sources of 11 heavy metals were analyzed from 342 surface soil samples collected from the central city of Chongqing in southwest China. The results showed that the main heavy metal elements under the first principal component loading were copper $(\mathrm{Cu})$, nickel(Ni), zinc $(\mathrm{Zn})$, manganese $(\mathrm{Mn})$, cadmium $(\mathrm{Cr})$, plumbum $(\mathrm{Pb})$ and cadmium $(\mathrm{Cd})$. The second principal component (F2) was mainly loaded with molybdenum (Mo), arsenic (As), mercury ( $\mathrm{Hg}$ ) and antimony (Sb), and the PCA-APCs receptor model of 11 heavy metals was constructed. The PCA-APCs receptor models of 11 heavy metals were constructed. The results of classification regression analysis confirmed the main sources of heavy metals. Population density mainly affected $\mathrm{Cu}(0.539)$, soil mainly affected $\mathrm{Ni}(0.411), \mathrm{Sb}(0.493), \mathrm{Zn}(0.472)$ and $\mathrm{Mn}$ (0.206), and water quality mainly affected $\mathrm{As}(0.453)$ and $\mathrm{Mo}(0.374)$. Air quality mainly affects $\mathrm{Cd}(0.332)$ and $\mathrm{Cr}(0.371)$, traffic activity mainly affects $\mathrm{Hg}(0.312)$, and slope mainly affects $\mathrm{Pb}(0.313)$. Hot spot analysis showed that heavy metals had a high degree of coincidence with environmental factors such as soil parent material, slope, soil type and traffic activities. The results of this study can be effectively used to make scientific decisions and strategies, and an effective strategy for prevention and control of soil heavy metal pollution should be formulated to protect the urban soil environmental quality.

Keywords Soil heavy metals, Influence Factor, PCA-APCS Receptor Model, Categorical regression analysis, Spatial analysis of hot spots

\section{Introduction}

Soil heavy metal pollution has become a major environmental safety problem in the world and has attracted great attention from the global society. Heavy metals exist in water and soil for a long time because they are difficult to be degraded by other organisms and accumulate strongly, and enter the food chain, directly or indirectly affecting human health (Almeida and Garrod, 2018). The identification of the main influencing factors of soil heavy metals can provide a basis for the analysis of the sources of soil heavy metal pollution.

The high content of heavy metals in soil is the result of various factors, which can be divided into natural factors and human factors. The natural factors include soil parent material, soil type and slope, etc., while the human factors include traffic, industrial activities, water quality, agricultural input, mineral mining, pesticides and fertilizers, etc (Bai, Ruan et al. 2018). For example, Huseyin (2018) believes that rock weathering is an important natural source of heavy metal pollution, and changes in the lithology, metal types and soil geochemistry of soil parent material all affect the spatial distribution of heavy metals. The main sources of heavy metals are human activities, such as mineral mining, coal burning, irrigating land with contaminated water and applying impure mineral fertilizers, which are among the pollution sources that increase the content of heavy metals in soil (Wang and Li et al., 2020). Such as: Selinus(2005) found that the continuous mining of metal mines led to a high concentration of cadmium in the plants near the waters in central Sweden. Birke(2017) revealed that industrial activities, urban agglomeration and fertilizer use were responsible for the high local concentrations of heavy metals $\mathrm{Cd}$ and $\mathrm{Hg}$ in European agricultural soils. These are the point pollution sources or non-point pollution sources that affect the high content of heavy metals. 
With the development and progress of industry, people have gradually realized the threat and influence of heavy metals on human body. Scholars began to study heavy metals in the 1980s and 1990s. DeRosa (1991) assessed the effects of lead, an environmental poison, on children's physical or intellectual development. Before 2000, the research focused on the spatial distribution and pollution assessment of heavy metal pollution. With the development of geostatistics, Kriging method and inverse distance weighted interpolation methods have been widely used in the study of spatial distribution. From 2000 to 2010, research focused on heavy metal risk assessment pollution index, spatial variation, biological stimulation, biological monitoring and other aspects. Since 2010, the monitoring of heavy metal pollution sources has become a hot topic. At present, the most widely used source analysis models in the field of soil mainly include APCS/MLR model, PMF model, Unmix model, Isotope ratio method, etc. Due to the differences in soil parent material, climate conditions and human interference, the sources of heavy metals vary greatly, so it is necessary to detect the specific sources of heavy metals in the site. For example, Liu (2021) found that the heavy metals $\mathrm{Hg}, \mathrm{Cd}, \mathrm{Cu}, \mathrm{Pb}$ and $\mathrm{Zn}$ in agricultural soils of southern Shandong Peninsula in China came from coal burning, agricultural practices, and industrial activities. Aguilera (2021) explained that the main sources of heavy metals $\mathrm{Pb}, \mathrm{Zn}, \mathrm{Cu}$ and $\mathrm{Cr}$ in street dust in Mexico City are human activities, possibly due to vehicle traffic. Ivankovic(2010) believed that the heavy metal Ni in the urban soil of Belgrade, Serbia was derived from peridotites and serpentinites, and $\mathrm{Pb}$ was derived from traffic activities.

Chongqing is one of the megacities in Chengdu-Chongqing region, an economic and political center in southwest China, a comprehensive transportation hub and the largest industrial and commercial city in the west of China. As a traditional heavy industrial city, industrial pollutant emission, mountainous landscape and humid climate all lead to the increase of heavy metal content in the soil, which in turn affects the health of local residents. There are serious regional haze phenomena in Chongqing and even the whole Sichuan-Chongqing region. Therefore, the investigation and source analysis of soil heavy metal pollution in this region are of great significance to ensure soil quality and food safety in this region.

The objectives of this study were to: (1) Field sampling and laboratory analysis were conducted in the central urban area of Chongqing to investigate the content of heavy metals in the regional soil. (2) PCA-APCS receptor model was used to analyze the internal relationship between soil heavy metal elements. (3) CATREG was used to analyze the relationship between heavy metals and environmental factors. (4) ArcGIS hotspot analysis was used to analyze the spatial variation of soil heavy metal content. This will provide more information to city planners and decision-makers to help them make decisions, promote the sustainable development and management of Chongqing, and provide them with valuable insights. Supplement analysis of the sources of heavy metal pollution in Sichuan and Chongqing areas, and provide basic data and theoretical support for the early warning and forecast, joint prevention and control of soil pollution.

\section{Study area}

Chongqing is located in the southwest of mainland China, the upper reaches of the Yangtze River, and the parallel range-valley region in the east of the Sichuan Basin, between $105^{\circ} 011^{\prime}-110^{\circ} 11^{\prime} \mathrm{E}$ and $28^{\circ} 100^{\prime}-32^{\circ} 13^{\prime} \mathrm{N}$. The topography of Chongqing gradually decreases from south to north to the Yangtze River Valley, with hills and low mountains mainly in the northwest and central part, Daba Mountain in the northeast and Wuling Mountain in the southeast (Deng and Li et al., 2020), Landform to hills, mountain - based, large slope area, known as the "mountain city" (Xu and Wang et al., 2018)。 The central urban area includes 6 districts of Yuzhong, Jiangbei, Dadukou, Shapingba, Nanan, Jiulongpo and 3 districts of Banan, Yubei and Beibei in the outer urban circle (Fig.1)。 


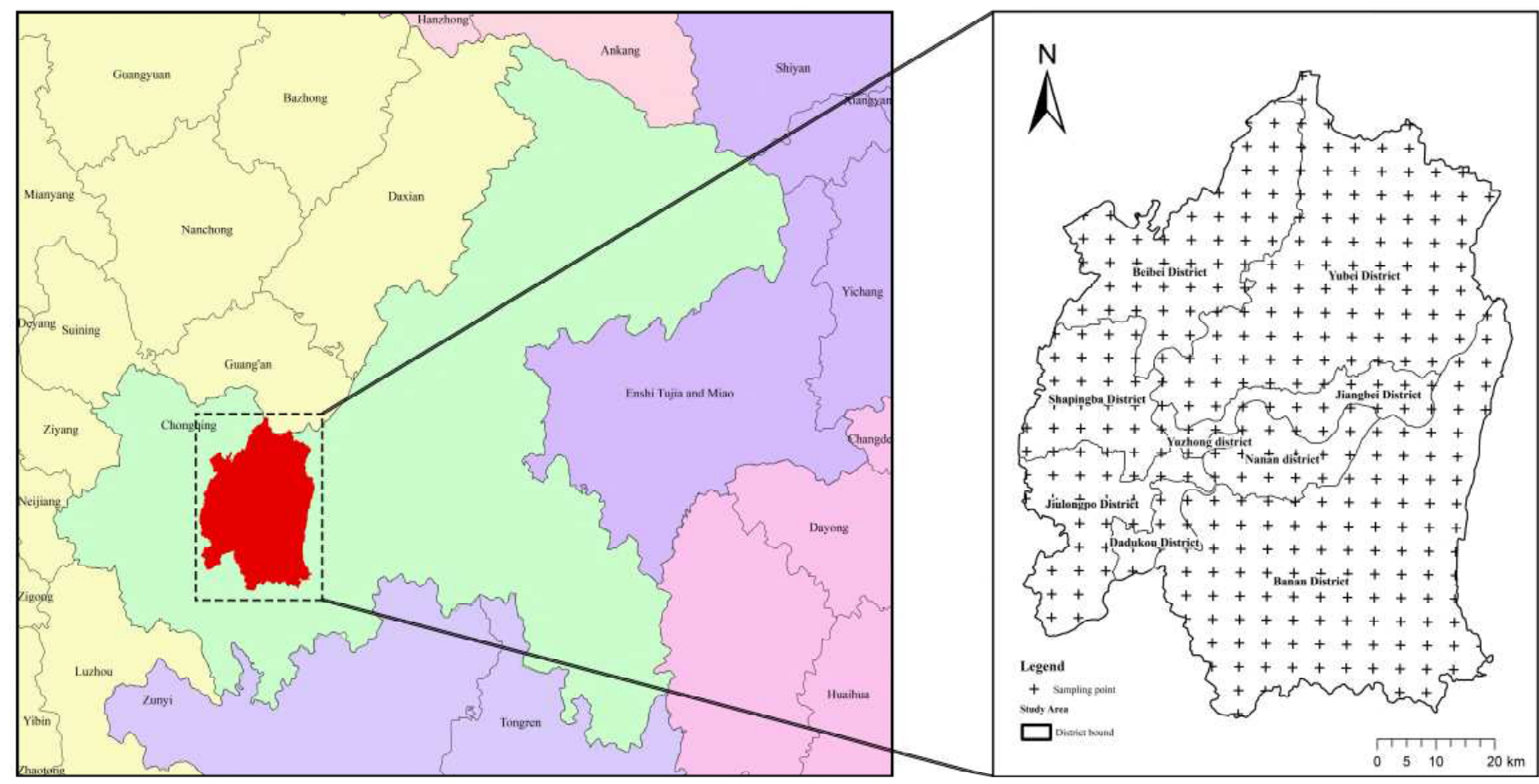

Fig.1 Study the distribution map of the location and sampling points Sample collection and testing

In accordance with the industry technical standards "Specification for Geochemical Assessment of Land Quality" (DZ/T0259-2016) and "Digestion of Total Metal Elements in Soil and Sediments by Microwave Digestion" (HJ832-2017) issued by the Ministry of Environmental Protection, surface soil samples of agricultural land were collected by grid with a sampling density of $4 \mathrm{~km}$ and a sampling depth of $40 \mathrm{~cm}$. A total of 342 single spot samples of surface soil were collected in three multi-point collection combinations within $100 \mathrm{~m}$ of the sampling center. Taking the sampling point located by GPS as the center, the four sampling points were determined by radiating $40 \mathrm{~m}$ to the periphery (Fig.1). When sampling, avoid special areas such as roads and ditches, and take $1 \mathrm{~kg}$ soil samples according to the method of quartering.

Samples collected in the field are sealed in plastic bottles and sent to the laboratory of Anhui Rock and Mineral Testing Center with national first-class qualification for testing. Laboratory, after receiving the sample soil samples after drying, removing sand, such as plant debris, grinding, agate mortar over $2 \mathrm{~mm}$ diameter soil sieve, regrinding all through 100 mesh sieve, among them with one-time grinding all through 100 mesh sieve is the best, with four points method take 200g sample save backup, according to take samples of $4 \mathrm{~g}$ in the mould with boric acid edge at the bottom, Under the pressure of 40 tons, the holding time is $20 \mathrm{~s}$, and the sample with diameter of $32 \mathrm{~mm}$ and thickness of $4 \mathrm{~mm}$ is pressed to carry out drift correction experiment. The detection limits of 11 heavy metals, such $\mathrm{As} \mathrm{Cr}, \mathrm{Pb}, \mathrm{Zn}$ and $\mathrm{As}$, in the samples were calculated using different determination methods. The detection lines were all up to $\mathrm{mg} \cdot \mathrm{kg}^{-1}$, which could meet the rapid analysis requirements of the II type of soil in the national soil environmental quality standard.

Table 1 Analytical method and detection limit of heavy metal elements

\begin{tabular}{ccr} 
Indicators & Assay method & Detection limit/ \\
\hline $\mathrm{Cr}$ & X-ray fluorescence spectrometry & 3 \\
$\mathrm{~Pb}$ & X-ray fluorescence spectrometry & 2
\end{tabular}




\section{PCA/APCS receptor model}

The purpose of the principal component is to compress the original several related variables into a few comprehensive variables through linear combination for investigation. Principal component analysis uses dimension-reduction to reveal the hidden relationship between variables and classifies elements according to correlations to judge the source of elements in each factor (Dong and Jia et al., 2018). However, it can only give the major contributing factors of each source in a qualitative way to explore the potential relationship between variables. The factor contribution of each element to the principal component cannot be expressed quantitatively.

The normalized factor fraction of PCA/APCS is obtained from the results of principal component analysis, and the calculation formula is as follows(Aelion and Davis et al., 2008; Aelion and Davis et al., 2008; Davis and Aelion et al., 2009):

$$
Z_{i j}=\frac{C_{i j}-\bar{C}_{i}}{\sigma_{i}}
$$

Where, $Z_{i j}$ is the concentration value after standardization (dimensionless); $C_{i j}$ is the measured value of heavy metal concentration. $c_{i j}$ and $\sigma_{i}$ are the mean concentration and standard deviation of element i, respectively.

The APCS of each heavy metal element can be obtained by subtracting the factor fraction of the 0 concentration sample from the factor fraction of each sample:

$$
\left(Z_{o}\right)_{i}=\frac{0-\bar{C}_{i}}{\sigma_{i}}=-\frac{C_{i}}{\sigma_{i}}
$$

where, $\left(z_{o}\right)_{t}$ is the factor fraction of concentration sample $0 ; b_{o i}$ is the constant term obtained by multiple linear regression of metal element $\mathrm{i} ; b_{p i}$ is the regression coefficient of source $\mathrm{p}$ to heavy metal element $\mathrm{i}$.

The corresponding regression coefficients can be obtained by multiple linear regression of APCS with metal concentration data. The regression coefficient converts APCS into the contribution of the concentration of each sample to each source of pollution. The specific calculation formula is as follows:

$$
\begin{gathered}
A P C S=Z_{i j}-\left(Z_{o}\right)_{i} \\
C_{i}=b_{o i}+\sum_{P=1}^{n}\left(\operatorname{APCS}_{P} \times b_{p i}\right)
\end{gathered}
$$


${ }_{A P C S_{P}}$ is the fraction of the adjusted factor $\mathrm{p} ;{ }^{A P C S_{P}} \times b_{p i}$ denotes the contribution of source p to the mass concentration of $C_{i}$; The mean of all samples represents the mean absolute contribution of the source.

\section{CATREG model}

In order to identify the relative importance of heavy metal influencing factor variables, the CATREG model, as a non-parametric multivariate regression analysis model, can use an optimal scaling program to scale dependent and independent variables and perform the analysis of categorical and numerical variables. It is usually used to test the effects of multiple predictors on dependent variables (Almeida and Garrod, 2018; Feng and Zhao et al., 2021). Classified regression (CATREG) was selected for analysis in this study. Discrete variables and prevariables were selected into the regression. Category quantization refers to quantizing class variables by a specific nonlinear transformation and then iterating directly to find the optimal equation. CATREG model is a classical linear regression model applied with transformation variables (Yang and Wang et al., 2020).

CATREG is an econometric method used to deal with data sets containing nominal, ordinal, and interval variables. In a simple linear regression model, a response variable is predicted from $\mathrm{m}$ predictive variables in $\mathrm{x}$ to try to find a linear combination $\mathrm{Xb}$ that is most correlated with it. The "optimal scaling" involved makes the feasible nonlinear function analysis between $\mathrm{Z}$ and $\sum_{j=1}^{m}\left(b_{j} \varphi_{j}\left(X_{i}\right)\right)$ and its expression is:

$$
\left\|X^{*} b-Z^{*}\right\|^{2} \text { where }\left\|X^{*} b-Z^{*}\right\|=\sqrt{\left(X^{*} b-Z^{*}\right)^{T}\left(X^{*} b-Z^{*}\right)}
$$

The classification variable $h_{j}$ defines the binary indicator matrix $G_{f}$ of n rows and columns $b_{f}$, where $h_{t j}$ defines $g_{t r(j)}$ as follows:

$$
\left\{\begin{array}{l}
g_{i r}(j)=1, h_{i j}=r \\
g_{i r}(j)=0, h_{i j} \neq r
\end{array}\right.
$$

The $\mathrm{r}=1,2 \ldots \ldots l_{j}$ is the running index, indicating the class number in $\mathrm{j}$. If the class quantization can be expressed by $y_{j}$, then the variable of transformation can be written as $G_{j} y_{j}$. For example, the weighted sum of the predictor variables can be expressed as:

$$
\sum_{j=1}^{m} b_{j} G_{j} y_{j}=X^{*} b
$$

This is the same as the standard linear model. Finally, CATREG is equivalent to a linear regression model, which can be expressed as follows:

$$
Z^{*}=X^{*} b+\varepsilon
$$

In the formula, $X^{*}$ represents the coefficient matrix, $Z^{*}$ is the observed value vector, $\mathrm{b}$ is the normalized coefficient vector, and $s$ is the error vector. The qualitative variables are transformed into quantitative variables through the optimal scaling process. Classification variables are quantified to reflect the characteristics of the original category, and the use of nonlinear transformations allows the analysis of variables at various levels to find the best fit model.

\section{Data source and processing}

The soil heavy metals data in the study area are the survey data of our research group in 2006. A total of 342 sampling points were set from all parts of Chongqing (Fig 1). The contents of $\mathrm{As}, \mathrm{Cd}, \mathrm{Cr}, \mathrm{Cu}, \mathrm{Hg}, \mathrm{Mn}, \mathrm{Mo}, \mathrm{Ni}, \mathrm{Pb}, \mathrm{Sb}$ and $\mathrm{Zn}$ were determined. 
For vegetation data, the 2008 images from Landsat8 image data were downloaded from the geo-spatial data cloud (http://www.gscloud.cn), and the images with less cloud cover and an accuracy of 30m were selected. The categories of air quality, population density and water quality were derived from Statistical Yearbook (2000-2010). In order to more accurately describe the impact of industrial activities on heavy metals, gross industrial product was used to represent the intensity of industrial activities. Population distribution (2000a) is the result of China's fifth population census. Land use data (0000) ", the elevation data (DEM) $(25,0000)$, the slope $(30 \mathrm{~m})$, traffic data $(25,0000)$ are from resources and environment data cloud platform (http://www.resdc.cn/default.aspx). Soil types (1:1000000) from Chinese soil database (http://vdb3.soil.csdb.cn/), soil parent material (1:50 0000) from China geological map.

In this study, ArcGIS10.5 software was used to process and collect data, and spatial interpolation method was used to obtain environmental factors, such as normalized vegetation index, air comprehensive quality index, slope, soil type, soil parent material, population density, water quality category, traffic activity and gross industrial product. Then, the environmental factor values were assigned to the sampling points, and the principal component receptor model was analyzed by R language, and the CATREG model was analyzed by SPSS24.0. Finally, ArcGIS is used to complete hot spot analysis and mapping.

\section{Results}

\section{Heavy metal content}

The characteristics of soil heavy metals in the central urban area of Chongqing were analyzed as follows (Table 2). In the study area, the variation coefficient of As was the highest (55.71\%), followed by Mo (54.69\%), and the variation coefficient of $\mathrm{Cr}$ was the lowest (14.86\%), with the maximum value of $126.094 \mathrm{mg} \cdot \mathrm{kg}^{-1}$ and the minimum value of $47.408 \mathrm{mg} \cdot \mathrm{kg}^{-1}$. Except for As and Mo elements, the coefficient of variation is greater than 0.5 , showing a weakly differentiated distribution. Other heavy metal elements are all less than 0.5 , including $\mathrm{Hg}, \mathrm{Cd}, \mathrm{Cu}, \mathrm{Mn}, \mathrm{Sb}, \mathrm{Ni}, \mathrm{Zn}, \mathrm{Pb}$ and $\mathrm{Cr}$, respectively, showing a uniformly weakly differentiated distribution.

Table 2 Characteristics of heavy metal content in soil in the study area

\begin{tabular}{|c|c|c|c|c|c|c|}
\hline \multirow{2}{*}{ Heavy metal } & \multicolumn{5}{|c|}{ Soil heavy metal content in the study area } & \multirow{2}{*}{$\begin{array}{c}\text { Background value of heavy metals in } \\
\text { soils of Chongqing }\left(\mathrm{mg} \cdot \mathrm{kg}^{-1}\right)\end{array}$} \\
\hline & $\operatorname{Max}\left(\mathrm{mg} \cdot \mathrm{kg}^{-1}\right)$ & $\operatorname{Min}\left(\mathrm{mg} \cdot \mathrm{kg}^{-1}\right)$ & $\operatorname{Mean}\left(\mathrm{mg} \cdot \mathrm{kg}^{-1}\right)$ & Standard deviation & $\mathrm{CV}(\%)$ & \\
\hline As & 21.180 & 1.965 & 5.802 & 3.232 & 55.71 & 6.62 \\
\hline $\mathrm{Cd}$ & 0.782 & 0.041 & 0.132 & 0.057 & 43.11 & 0.28 \\
\hline $\mathrm{Cr}$ & 126.094 & 47.408 & 76.559 & 11.375 & 14.86 & 74.4 \\
\hline $\mathrm{Pb}$ & 42.068 & 12.703 & 25.548 & 4.057 & 15.88 & 28.1 \\
\hline $\mathrm{Cu}$ & 76.600 & 6.208 & 23.992 & 8.572 & 35.73 & 24.6 \\
\hline $\mathrm{Zn}$ & 144.607 & 37.447 & 75.579 & 13.034 & 17.25 & 81.9 \\
\hline $\mathrm{Ni}$ & 62.440 & 15.470 & 30.499 & 6.769 & 22.20 & 31.6 \\
\hline $\mathrm{Hg}$ & 0.162 & 0.015 & 0.0528 & 0.025 & 46.63 & 0.069 \\
\hline $\mathrm{Sb}$ & 1.170 & 0.244 & 0.644 & 0.163 & 25.25 & 0.7 \\
\hline $\mathrm{Mn}$ & 1584 & 107.900 & 573.316 & 184.685 & 32.21 & 615 \\
\hline Mo & 3.197 & 0.100 & 0.560 & 0.306 & 54.69 & 0.5 \\
\hline
\end{tabular}


The statistical value obtained by KMO (Kaiser-Meyer-Olkin) test is 0.870 , and the concomitant probability of Bartlett spherical test is 0.000 . Therefore, the data can be analyzed by principal component analysis (PCA), and the analysis results are shown in Table 3. After orthogonal Varimax rotation of the Kaiser normalized factors, two principal components with eigenvalues greater than 1 were obtained. The variance contribution rates were $48.855 \%$ and $15.788 \%$, respectively, and the cumulative contribution rates were $64.643 \%$. The first principal component (F1) loading heavy metal elements were $\mathrm{Cu}(0.882), \mathrm{Ni}(0.879)$, $\mathrm{Zn}$ (0.798), Mn (0.728), As (0.718), $\mathrm{Cr}$ (0.688), Mo (0.661), Sb (0.632), $\mathrm{Pb}(0.629)$ and $\mathrm{Hg}(0.552)$ respectively, the lowest loading element is $\mathrm{Cd}(0.361)$; The second principal component (F2) with high heavy metal load was Mo (0.586), As (0.569), Hg (0.517) and $\mathrm{Sb}(0.470)$.

According to the receptor model of each element (Fig.2), the contributions of principal components $F_{1}$ and $F_{2}$ to each element were calculated respectively, and the statistical results were shown in Figure 2. The heavy metal sources of $\mathrm{Cr}, \mathrm{Cu}, \mathrm{Mn}, \mathrm{Ni}, \mathrm{Pb}$ and and $\mathrm{F}_{2}$ to As, Mo and $\mathrm{Sb}$ were not significantly different. In addition, $\mathrm{Cd}$ is mainly controlled by other sources. Except As and Mo, other elements are controlled by other sources to varying degrees.

Table 3 Principal component analysis/absolute principal component fraction (PCA/APCS) receptor model

\begin{tabular}{clcc}
\hline Elemental & \multicolumn{1}{c}{ Receptor model } & Sig & $\mathrm{R}^{2}$ \\
\hline $\mathrm{As}$ & $\mathrm{C}(\mathrm{As})=2.324 \mathrm{APCS}_{\mathrm{F} 1}+1.843 \mathrm{APCS}_{\mathrm{F} 2}+5.802$ & 0.000 & 0.916 \\
$\mathrm{Cd}$ & $\mathrm{C}(\mathrm{Cd})=0.021 \mathrm{APCS}_{\mathrm{F} 1}-0.004 \mathrm{APCS}_{\mathrm{F} 2}+0.132$ & 0.000 & 0.367 \\
$\mathrm{Cr}$ & $\mathrm{C}(\mathrm{As})=$ 7.834APCS $\mathrm{F}_{\mathrm{F} 1}-3.351 \mathrm{APCS}_{\mathrm{F} 2}+76.559$ & 0.000 & 0.748 \\
$\mathrm{Cu}$ & $\mathrm{C}(\mathrm{Cu})=$ 7.575APCS $\mathrm{A}_{\mathrm{F} 1}-1.478 \mathrm{APCS}_{\mathrm{F} 2}+23.992$ & 0.000 & 0.899 \\
$\mathrm{Hg}$ & $\mathrm{C}(\mathrm{Hg})=0.014 \mathrm{APCS}_{\mathrm{F} 1}+0.013 \mathrm{APCS}_{\mathrm{F} 2}+0.053$ & 0.000 & 0.756 \\
$\mathrm{Mn}$ & $\mathrm{C}(\mathrm{Mn})=0.728 \mathrm{APCS}_{\mathrm{F} 1-0.4 \mathrm{APCS}_{\mathrm{F} 2}+30.482}$ & 0.000 & 0.831 \\
$\mathrm{Mo}$ & $\mathrm{C}(\mathrm{Mo})=0.203 \mathrm{APCS}_{\mathrm{F} 1}+0.180 \mathrm{APCS}_{\mathrm{F} 2}+0.56$ & 0.000 & 0.884 \\
$\mathrm{Ni}$ & $\mathrm{C}(\mathrm{Ni})=5.96 \mathrm{APCS}_{\mathrm{F} 1-1.603 \mathrm{APCS}_{\mathrm{F} 2}+30.499}$ & 0.000 & 0.910 \\
$\mathrm{~Pb}$ & $\mathrm{C}(\mathrm{Pb})=2.555 \mathrm{APCS}_{\mathrm{F} 1}-1.327 \mathrm{APCS}_{\mathrm{F} 2}+25.548$ & 0.000 & 0.709 \\
$\mathrm{Sb}$ & $\mathrm{C}(\mathrm{Sb})=0.103 \mathrm{APCS}_{\mathrm{F} 1}+0.077 \mathrm{APCS}_{\mathrm{F} 2}+0.644$ & 0.000 & 0.787 \\
$\mathrm{Zn}$ & $\mathrm{C}(\mathrm{Zn})=10.420 \mathrm{APCS}_{\mathrm{F} 1}-4.850 \mathrm{APCS}_{\mathrm{F} 2}+75.578$ & 0.000 & 0.880 \\
\hline
\end{tabular}




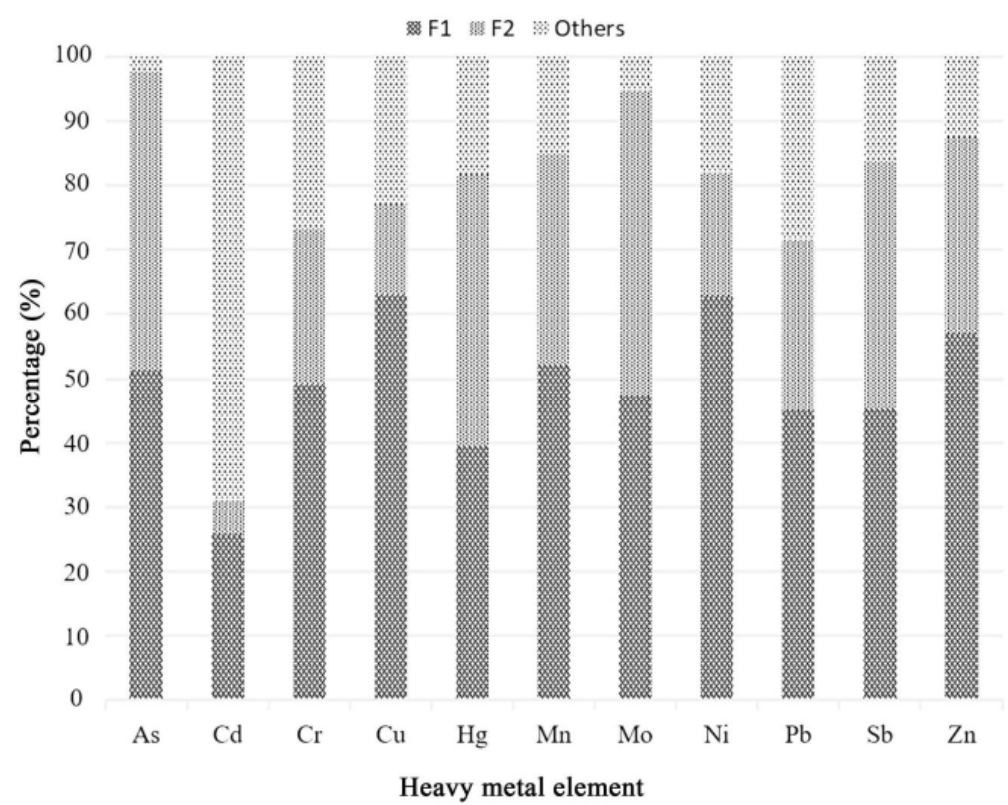

Fig.2 Sources statistics of soil heavy metal elements

\section{Analysis of the influencing factors of heavy metal distribution}

$\mathrm{R}^{2}$ values of the fitting models for the 11 heavy metals ranged from 0.449 to 0.734 , and all the fitting models passed the $\mathrm{F}$ test $(\mathrm{P}<0.05)$, showing statistical significance. Through collinearity diagnosis, the variance inflation factor values of all variables ranged from 1.16 to 2.263 (VIF < 3), and the tolerance ranged from 0.442 to 0.862 . The tolerance was high enough to ensure that the multicollinearity problem could be excluded. For the same heavy metal, the regression coefficients and significance of different influencing factors are different (Table 4). Beta is used to compare the absolute effect or contribution of each coefficient. The results of the regression coefficient test by the sources of each element, sig, are all significant by coefficient test. On the basis of significance check, the relative importance measure is helpful to explain the contribution value of CATREG model to regression.

Compared with other important values, numerical values indicate the relevant importance of these factors. Factors that significantly affect the content of As in soil are water environment (0.453), soil type (0.236) and slope (0.177); Air quality (0.332) and soil type (0.183) significantly affected the content of Cd in soil; Air quality (0.371) and NDVI (0.184) had significant effects on soil $\mathrm{Cr}$ content; Population density (0.539) and soil parent material (0.207) significantly affected the $\mathrm{Cu}$ content in soil; The distribution of $\mathrm{Hg}$ in soil was mainly affected by traffic activity (0.312), slope (0.223) and soil type (0.221); Slope (0.206) and soil parent material (0.201) significantly affected the Mn content in soil; Water environment (0.374) was the most significant factor affecting soil Mo content, followed by industrial activities (0.232); Soil type (0.411) and soil parent material (0.211) significantly affected the Ni content in soil; Slope (0.313) and air quality (0.239) were significant factors affecting Pb content in soil; Soil type (0.493) and population density (0.155) significantly affected the content of Sb in soil; Soil parent material (0.472) and slope (0.324) significantly affected the content of $\mathrm{Zn}$ in soil.

Table 4 Importance of different environmental factors on the distribution of heavy metals

\begin{tabular}{cccccccccccc}
\hline Influence factor & $\mathrm{As}$ & $\mathrm{Cd}$ & $\mathrm{Cr}$ & $\mathrm{Cu}$ & $\mathrm{Hg}$ & $\mathrm{Mn}$ & $\mathrm{Mo}$ & $\mathrm{Ni}$ & $\mathrm{Pb}$ & $\mathrm{Sb}$ & $\mathrm{Zn}$ \\
\hline Transportation & -0.006 & 0.041 & -0.011 & 0.004 & 0.312 & 0.005 & 0.001 & 0.116 & -0.001 & 0.01 & 0.216 \\
activities & & & & & & & & & & &
\end{tabular}




$\begin{array}{ccccccccccccccc}\text { Industrial activity } & 0.006 & 0.016 & -0.018 & 0.072 & 0.001 & 0.08 & 0.232 & 0.06 & 0.098 & 0.04 & 0.025 \\ \text { Air quality } & 0.101 & 0.332 & 0.371 & 0 & 0.016 & 0.11 & 0.101 & 0.056 & 0.239 & 0.023 & 0.071 \\ \text { Soil parent material } & -0.065 & 0.25 & 0.034 & 0.207 & 0.018 & 0.201 & 0.004 & 0.211 & 0.224 & 0.128 & 0.472 \\ \quad \text { Slope gradient } & 0.177 & 0.149 & 0.181 & 0.002 & 0.223 & 0.206 & 0.086 & 0.05 & 0.313 & 0.08 & 0.324 \\ \text { Density of population } & 0.069 & 0.002 & 0.012 & 0.539 & 0.062 & 0.163 & 0.145 & 0.005 & 0.174 & 0.155 & 0.009 \\ \quad \text { Agrotype } & 0.236 & 0.183 & 0.112 & -0.017 & 0.221 & 0.066 & 0.019 & 0.411 & -0.018 & 0.493 & -0.004 \\ \quad \text { NDVI } & 0.03 & 0.009 & 0.184 & 0.015 & 0.001 & 0.136 & 0.037 & -0.013 & 0.036 & 0.046 & -0.136 \\ \text { Water environment } & 0.453 & 0.017 & 0.134 & 0.178 & 0.147 & 0.034 & 0.374 & 0.106 & -0.065 & 0.024 & 0.021\end{array}$

\section{Analysis of spatial distribution of heavy metals in soil}

According to the importance of the influence of different environmental factors on the distribution of heavy metals in Table 4, the map and analysis were made according to the maximum influence factor of each heavy metal, and the corresponding relationship between the distribution of heavy metals in soil and the spatial distribution of environmental factors was revealed through the hot spot analysis of heavy metals in soil (Fig.3).

The highest hot spot values (99\% confidence interval) of soil heavy metal As in the study area were mainly distributed in the north and west of the study area. High hot spot values (95\% confidence interval) and high hot spot values (90\% confidence interval) are distributed in a wide range, located in the north and west of the study area, and in the east of the concentrated distribution area, adjacent to the secondary water environment area. Overall, As element has a great overlap with the secondary water environment area. The highest hot spot value of soil heavy metal $\mathrm{Cd}$ in the study area is mainly concentrated in the southwest of the study area, and its air quality comprehensive index is at the overall medium level (4.22 4.23); The high hot spot values were concentrated in the western region, and the AQI was between 4.24 and 4.32. The high hot spot values are mainly distributed in the northern and central regions, and the AQI range is mainly less than 4.05 and 4.24 to 4.32

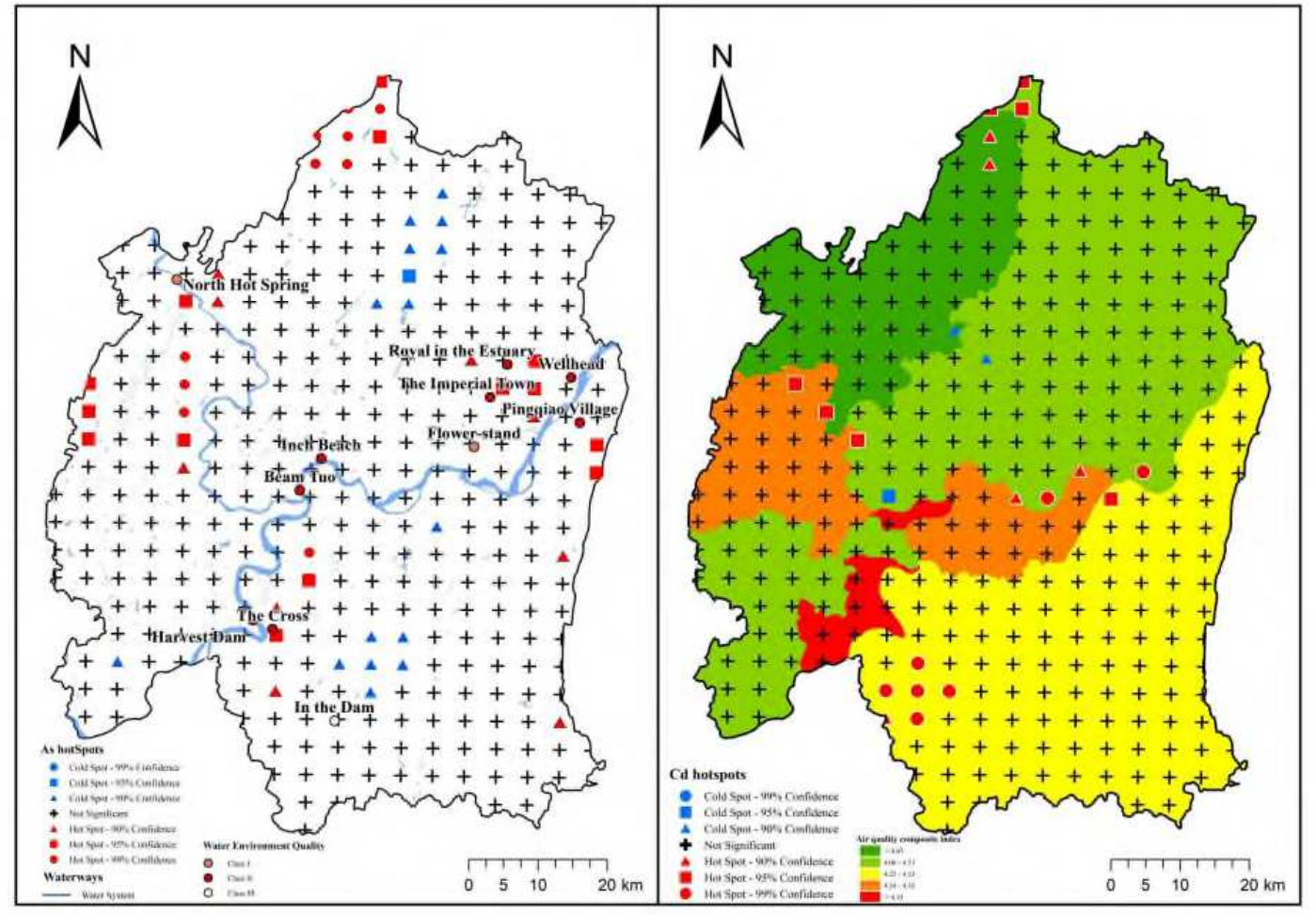

Fig.3 Spatial corresponding distribution and influencing factors of soil heavy metal hot spots: As(left) and Cd(right) 

quality composite index was mainly concentrated in the area with good air quality composite index, such as the area less than 4.05 and the area from 4.06 to 4.21 (Fig.4).The hot spot values of $\mathrm{Cu}$ in soil are mainly distributed in the northern, western and eastern regions, and The areas with the highest hot spot values are mainly distributed in the surrounding areas with population density greater than $3000 / \mathrm{km} 2$ and 1000 to $3000 / \mathrm{km} 2$.

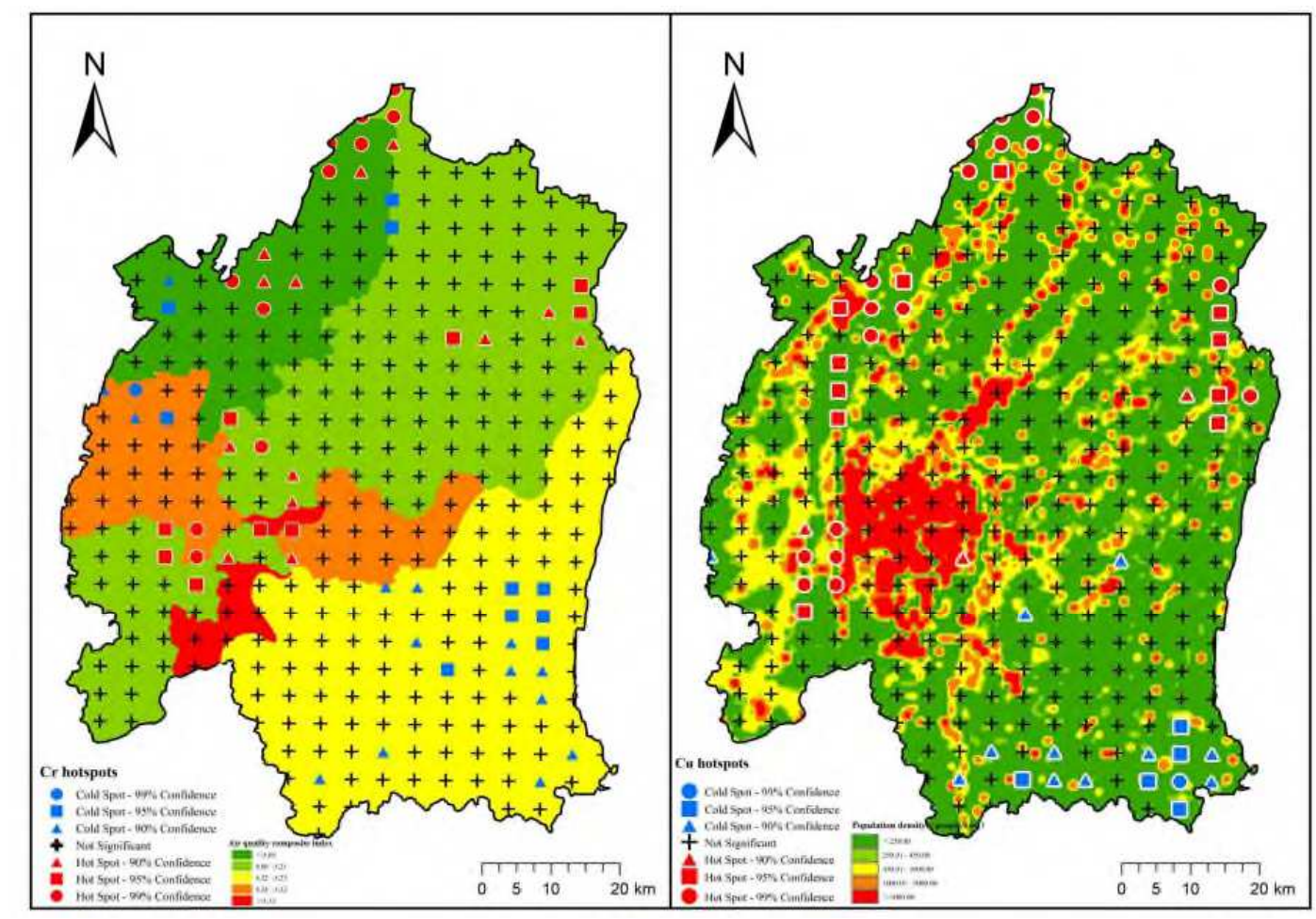

Fig.4 Spatial distribution and influencing factors of soil heavy metal hot spots: $\mathrm{Cr}(\mathrm{left})$ and $\mathrm{Cu}$ (right)

Soil heavy metal $\mathrm{Hg}$ hotspots were concentrated in the middle of the study area, concentrated in the road areas less than $70 \mathrm{~m}$ and 70 to $150 \mathrm{~m}$ away from the road (Fig.5). The hot spots of $\mathrm{Mn}$ in the soil were distributed in blocks in the west, north and east, with the characteristics of slope distribution and the tendency of diffusion from the center to the periphery. 


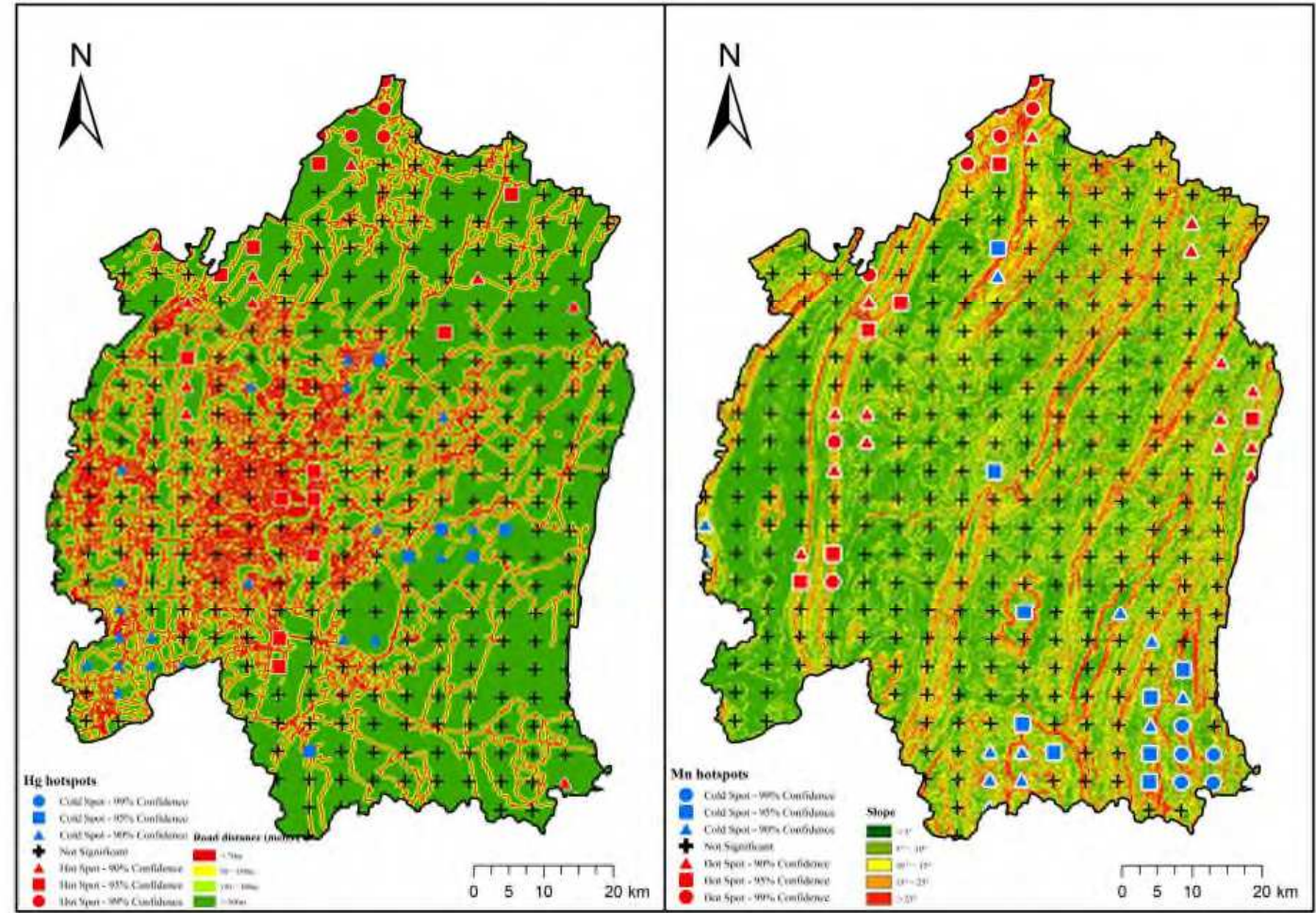

Fig.5 Spatial distribution and influencing factors of soil heavy metal hot spots: $\mathrm{Hg}$ (left) and $\mathrm{Mn}$ (right)

The hot spots of soil heavy metals Mo were mainly distributed in the northern, eastern and southwestern areas of the study area, and the eastern and southwestern areas were located in the secondary water environment area (Fig.6). The highest hot spots of heavy metal $\mathrm{Ni}$ in soils were mainly distributed in the north and northwest of the study area, mainly in the areas of yellow soil, brown soil and limestone soil. The high hot spot values were distributed in the western region, and the soil types were yellow soil, limestone soil and neutral purple soil. The higher hot spot values were distributed in the eastern and southwestern regions, which were located in the neutral purple soil and yellow soil.

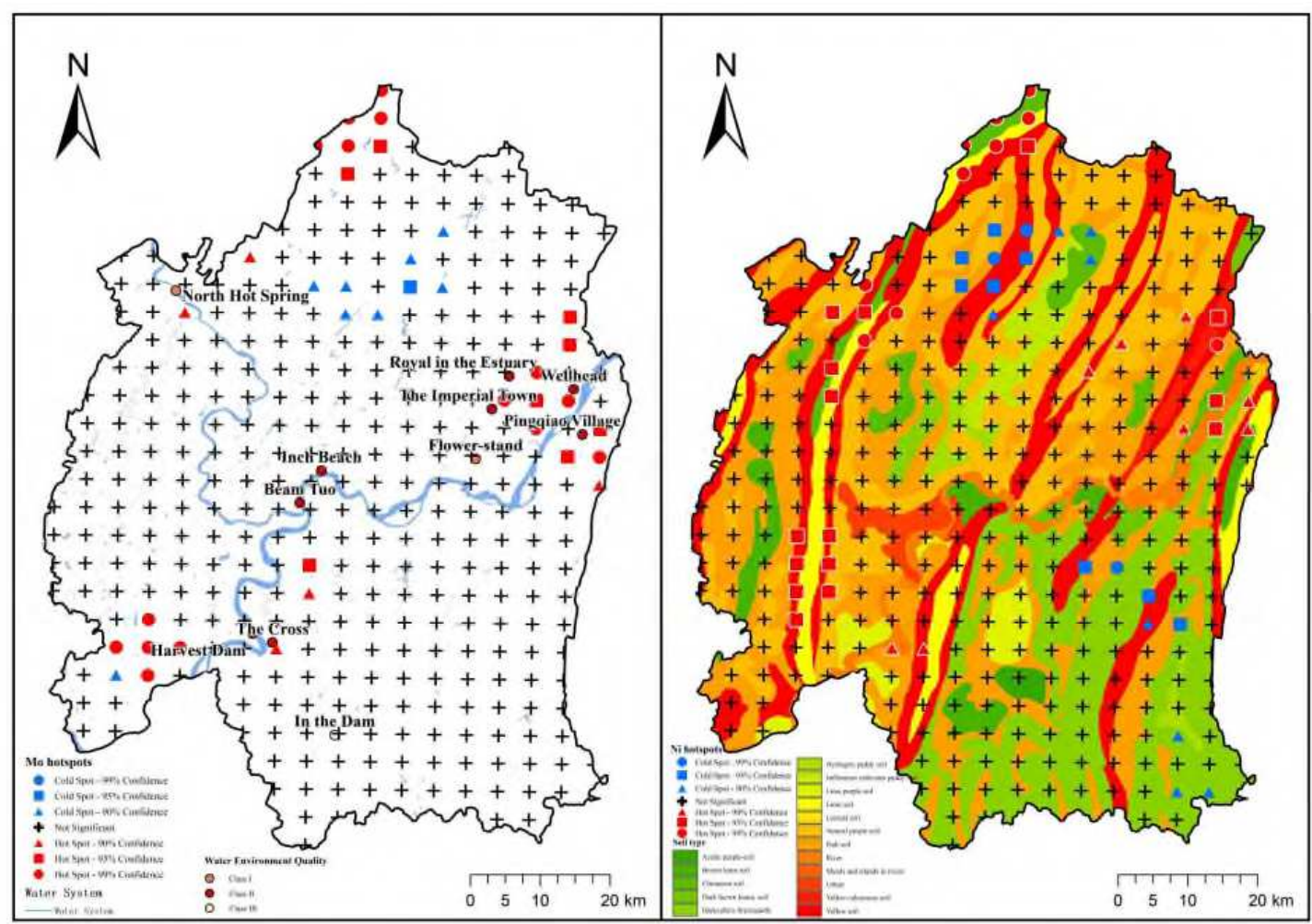



mostly between $10^{\circ}$ and $25^{\circ}$ (Fig.7).The highest hot spot value, high hot spot value and high hot spot value of $\mathrm{Sb}$ in the study area were banded and distributed along yellow soil, yellow limestone soil and limestone soil.

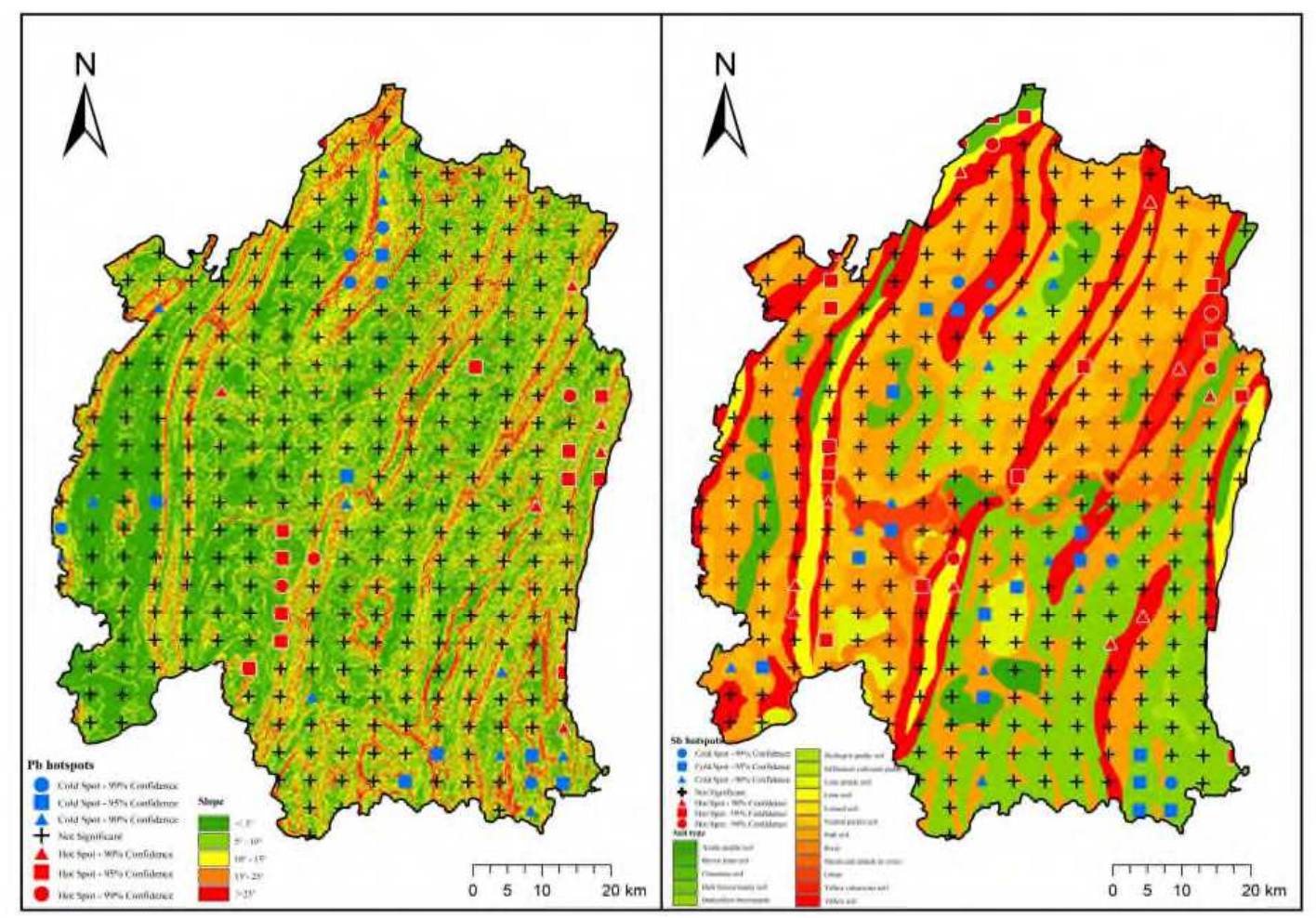

Fig.7 Spatial corresponding distribution and influencing factors of soil heavy metal hot spots: $\mathrm{Pb}$ (left) and Sb(right)

Triassic and the Lei of the Middle Triassic, the Jialingjiang group limestone of the Lower Triassic and the Feixianguan group marl of the Lower Triassic (Fig.8). 


\section{Discussion}

Fig.8 Spatial distribution and influencing factors of soil heavy metal hot spots: $\mathrm{Zn}$

PCA is widely used to identify possible sources of interrelated heavy metals, but PCA does not consider the importance of each index on the impact of soil heavy metals, resulting in the failure to identify important indicators (Zhang and Huang et al., 2020; Shao and Hu et al., 2021). The results of this study show that the principal component analysis model can only analyze that $\mathrm{Cr}, \mathrm{Cu}, \mathrm{Mn}, \mathrm{Ni}$ and $\mathrm{Pb}$ are affected by $\mathrm{F} 1, \mathrm{Hg}$ is affected by F2, and $\mathrm{As}, \mathrm{Mo}, \mathrm{Sb}, \mathrm{Zn}$ and $\mathrm{Cd}$ are affected by other factors. Soil use and laboratory analysis at a landfill site in Enugu State, Nigeria, using PCA, identified the first principal component (36\%) and second principal component $(28.2 \%)$ as e-waste disposal and the third principal component (10.2\%) from household and other forms of cosmetics(Mama and Nnaji et al., 2021). Principal component analysis of heavy metals in agricultural soils of Kermansha province in western Iran showed that $\mathrm{As}, \mathrm{Cd}, \mathrm{Cu}, \mathrm{Pb}, \mathrm{Se}$ and $\mathrm{Zn}$ were anthropogenic, while $\mathrm{Cr}$ and $\mathrm{Ni}$ were geo-derived (Rahman and Jolly et al., 2021).Based on the analysis of heavy metals in the park soils of Delhi, India, PC1 has a high load of Fe, Mn, Co and $\mathrm{Zn}$, which indicates that the crustal origin is mainly influenced by human beings; The content of Ni and $\mathrm{Zn}$ in PC2 is high, which is mainly from electroplating and electroplating process (Siddiqui and Khillare et al., 2020)。Principal component analysis can only analyze the approximate source points of soil heavy metals, but does not specify the specific influencing factors. Therefore, on this basis, this paper uses CATREG model to further analyze the relationship between heavy metals and environmental factors.

Classified regression is a suitable method to identify the factors affecting soil heavy metal content. Previous studies have shown that Austrian scholar Claudia Gundacker(2009) conducted a bivariate analysis through classification regression (CATREG) to explain the relationship between $\mathrm{Pb}$ and $\mathrm{Hg}$ exposure and genetic background. Yang (2020) firstly applied the classification regression analysis to the analysis of soil heavy metals, and found that the soil parent material, soil type, land use type and industrial activities were the main factors affecting the content of heavy metals in the soil of Beijing. This study found that soil, topography, population density, air quality, traffic and water sources were the main sources of heavy metals in the soil of Chongqing city. 


\section{Heavy metal content analysis}

Previous studies on heavy metals have shown that different land use types lead to different levels of soil heavy metal pollution (Ma and Jia et al., 2017). The results of this study show that the average levels of $\mathrm{Mn}, \mathrm{Cr}, \mathrm{Zn}, \mathrm{Ni}, \mathrm{Pb}, \mathrm{Cu}, \mathrm{As}, \mathrm{Sb}, \mathrm{Mo}$, $\mathrm{Cd}$ and $\mathrm{Hg}$ in the soil of Chongqing city center were 573.32, 76.56, 75.58, 30.50, 25.55, 23.99, 5.80, 0.64, 0.56, 0.13, $0.05 \mathrm{mg} / \mathrm{kg}$, respectively. Only $\mathrm{Cr}$ and Mo exceeded the background value of heavy metals in Chongqing soil by $74.4 \mathrm{mg} / \mathrm{kg}$ and $1.12 \mathrm{mg} / \mathrm{kg}$. Previous studies have shown that according to the National Environmental Protection Administration of China (GB156181995), the concentrations of $\mathrm{Pb}, \mathrm{Cu}, \mathrm{Cr}, \mathrm{As}, \mathrm{Hg}, \mathrm{Ni}$ and $\mathrm{Zn}$ in the soil in Tongnan District of Chongqing are lower than the safe threshold concentration, and the concentrations of Cd are higher than the safe threshold (Ma and Jia et al., 2017). The contents of heavy metals $\mathrm{Cd}, \mathrm{Hg}, \mathrm{Cr}, \mathrm{Cu}, \mathrm{Zn}$ and $\mathrm{Pb}$ in the soil of Rhizus monkey peach garden in Qianjiang District of Chongqing are higher than the national background value, and the contents of heavy metals in the soil of different orchards are also different (Yan and Ding et al., 2021). Compared with foreign countries, the contents of $\mathrm{As}$ and $\mathrm{Cu}$ in agricultural soils of Eggred County in southern Iran are close to the background values, while the contents of $\mathrm{Cd}$ are higher than the corresponding background values (Sabet Aghlidi and Cheraghi et al., 2020). Therefore, the degree of human disturbance in different areas leads to different levels and concentrations of heavy metals in the soil.

\section{Environmental factors affecting heavy metals}

\section{Soil and Terrain}

Soil types have significant effects on spatial hot spot distribution patterns of $\mathrm{Ni}$ and $\mathrm{Sb}$ in the study area.On the whole, the heavy metals in the two soils were distributed banded along the trend of yellow soil, yellow limestone soil and lime (rock) soil. Harley T. Davis(2009) pointed out that different soil types have different parent material, drainage capacity, texture $\mathrm{pH}$ and $\mathrm{pH}$, which have different effects on the migration and accumulation of heavy metals, leading to the depletion and enrichment of some elements in different land types. Soil types such as yellow soil and calcareous soil where $\mathrm{Ni}$ and $\mathrm{Sb}$ are concentrated have poor drainage, and their parent materials are all kinds of acidity, basic rocks and carbonate, which are slightly acidic or alkaline. In addition, factors such as soil $\mathrm{pH}$ and depth of underground water table should be considered.

Soil parent material is one of the factors that affect the concentration of heavy metals(Xu and Zhang et al., 2021). Zn elements in the surrounding areas, such as the Xujiahe Longstone Sandstone of Upper Triassic, Jialingjiang Formation of Lower Triassic and Leikoupo Formation of Middle Triassic, are distributed in clusters or bands. Previous studies have shown that a potential $\mathrm{Zn}$ conversion pathway exists in the subsurface environment, and found that sphalerite is the main phase of zinc concentrate, while quartz, iron-rich sphalerite $(\mathrm{ZnS})$ and zinc oxide $(\mathrm{ZnO})$ are the main phase of roadside dust.(Kwon and Lee et al., 2017).These results indicate that the spatial distribution of $\mathrm{Zn}$ in this region is closely controlled by soil parent material, which is of important reference significance for the interpretation of its source and distribution.

In the study area, mountains and slopes were cut into a large number of urban clusters by rivers. Slope factor is particularly important for the analysis of the source of heavy metals. The hot spots of $\mathrm{Mn}$ in the soil were distributed along the slope direction and tended to diffuse from the center to the periphery, and the slope of the hot spots of $\mathrm{Pb}$ was mostly between $10^{\circ}$ and $25^{\circ}$. The results showed that heavy metals accumulated in slope soil to a certain extent under the influence of long-term soil erosion, slope runoff and slope gravity settlement (Deng and Chen et al., 2018)。

\section{Population density and air quality}

Different population density is closely related to the accumulation of heavy metal $\mathrm{Cu}$ in soil. Population density is one of the important sources of soil heavy metal (Manuel Trujillo-Gonzalez and Aurelio Torres-Mora et al., 2016)。Based on the analysis of 
the physical and chemical properties, total and chemical forms of $\mathrm{Cu}$ in cities and soils with different population densities in Murcia, southeast Spain, the study shows that the behavior of $\mathrm{Cu}$ in soil dust and soil is affected by physical and chemical properties and total concentrations(Moros and Martinez-Sanchez et al., 2009). Heavy metals in road dust in Rafsanjan, Iran were investigated. The enrichment factor (EF) evaluation results showed that $\mathrm{Cu}$ was the most concerned pollutant. It was found that $\mathrm{Cu}$ was mainly derived from human factors, such as industrial and chemical activities, and heavy traffic(Mirzaei Aminiyan and Baalousha et al., 2018). H. Khademi(2020) proposed that the concentration of $\mathrm{Cu}$ was significantly correlated with particle size, and found that the particle size dependence of metal concentration and element enrichment degree in street dust were higher than those in urban soil, indicating that anthropogenic pollution contributed more to dust. This study shows that the higher the population density in Chongqing downtown, the greater the content of heavy metal $\mathrm{Cu}$ in the soil.

The results of this study show that the heavy metals $\mathrm{Cr}$ and $\mathrm{Cd}$ in the soil of Chongqing city center mainly come from the air environment, and the hot spot value of $\mathrm{Cr}$ is distributed in the areas with high air quality comprehensive index, on the contrary, the hot spot value of $\mathrm{Cd}$ is mainly distributed in the areas with medium air quality comprehensive index. Previous studies have shown that in the mountainous region of Asturias in the northwest of Spain, the sources of $\mathrm{Cr}$ and $\mathrm{Cd}$ in the soil are mainly from local air pollution-related factors, such as heavy metals released by vegetation combustion (Fernández and Cotos-Yáñez et al., 2018). Xiaojia Chen (2019) collected road dust samples from Beihai and Shanghai in order to explore the differences of heavy metal characteristics in air quality of different environments, and found that $\mathrm{Cd}$ is a traffics-derived metal, and $\mathrm{Cr}$ may be affected by natural sources. Air pollutants containing $\mathrm{Cr}$ and $\mathrm{Cd}$ were produced after the burning of peat in Malaysia, and the two heavy metal elements were found to be moderately enriched in the soil by atmospheric deposition (Othman and Latif, 2013). In conclusion, the characteristics of soil $\mathrm{Cr}$ and $\mathrm{Cd}$ heavy metals are different due to the different environmental air quality levels in different regions.

\section{Transport and Water}

Urban street dust is a mixture of mineral composition, organic matter and elemental carbon. Heavy metals contained in the dust of motor vehicles and building smoke on traffic roads are one of the main sources of urban dust (Amato and Pandolfi et al., 2009; Kim and Park et al., 2016). The heavy metal Hg in the soil of the study area was concentrated in the areas with dense roads and close to roads, indicating that the high content of $\mathrm{Hg}$ was one of the main substrates of street dust in the study area. Previous studies have shown that the highest average concentrations of mercury in TSP and dry deposition occur in industrial areas, but in industrial areas, metal product manufacturing and heavy traffic are the sources of high concentrations of mercury at industrial sampling sites (Fang and Lo et al., 2011). In addition, Akhter, M.S(1993)studied the dust of 106 streets and families in Bahrain and concluded that motor vehicles were the main source of heavy metals in the dust samples, revealing the close relationship between heavy metals in Bahrain and population density and traffic. The above studies are consistent with the relationship between $\mathrm{Hg}$ element and traffic road in the study area, which indicates that both industrial activities and traffic are important sources of $\mathrm{Hg}$. However, the influence of industrial production on $\mathrm{Hg}$ in the study area remains to be discussed.

Water is an important carrier and pathway for the movement of heavy metals. The Yangtze River and the Jialing River traversing the study area are the core factors for human survival and industrial development. Surface runoff and the industrial and agricultural production of soil in drinking water sources can import a large amount of heavy metals into the environment, resulting in the accumulation of heavy metals in the soil in drinking water sources (Davis and Aelion et al., 2009; Liu and Jiang et al., 2018). The hot spot distribution of As and Mo in soil was similar, and mainly distributed in the secondary water environment area in the east of the study area in three aggregates. Ezekwe (2012) explored the relationship between heavy metal pollution and 
groundwater in the Stone Horn mining area in southeastern Nigeria, and concluded that there was a close relationship between heavy metal pollution and water quality. Some heavy metals in river sediments in the water source area mainly come from the leaching of the surrounding soil. In this study, the eastern area where As and Mo are enriched is the downstream area of the river in the study area, which is presumed to be the joint result of heavy metals moving along the river and enrichment in the surrounding area.

\section{Conclusions and policy implications}

The main sources of heavy metals in soil were analyzed, and the heavy metal data were analyzed by using principal component analysis method and classification regression method. Principal component receptor model is widely used to determine the source of heavy metals, but the results are not accurate enough. Since the CATREG model cannot obtain all the data of the influencing factors, the results may have some deviation, but this method can accurately identify the specific category of the influencing factors. In general, in addition to normalized vegetation index and gross industrial product, slope, soil type, soil parent material and population density are the important factors that affect the soil heavy metal content in Chongqing. The results show that As and Mo hotspots are mainly concentrated in the area with secondary water environment, $\mathrm{Cd}$ and $\mathrm{Cr}$ hotspots are concentrated in the area with air quality index 4.06 4.23, Mn and $\mathrm{Zn}$ hot spots are concentrated in the area with Triassic parent material, $\mathrm{Ni}$ and $\mathrm{Sb}$ hot spots are concentrated in the area with yellow soil and limestone (rock) soil, and $\mathrm{Pb}$ hot spots are concentrated in the area with slope of $10^{\circ} \sim 25^{\circ}$. Hg hot spots are concentrated in the area with road distance less than $150 \mathrm{~m}$, and $\mathrm{Cu}$ hot spots are concentrated in the area with population density $>1000 / \mathrm{km}^{2}$. On the whole, the heavy metal pollution areas are mainly concentrated in the north, east and middle of the central city. The research results provide reference for soil pollution prevention and control.

\section{Declarations}

\section{Ethical Approval}

This topic has been approved by the Ethics Committee of College of Tourism and Urban and Rural Planning, Chengdu University of Technology/ Sichuan Key Research Base of Social Sciences (Extended) National Park Research Center.

\section{Consent to Participate}

Written informed consent for publication was obtained from all participants.

\section{Consent to Publish}

Author confirms: The article described has not been published before; Not considering publishing elsewhere; Its publication has been approved by all co-authors; Its publication has been approved (acquiesced or publicly approved) by the responsible authority of the institution where it works. The author agrees to publish in the following journals, and agrees to publish articles in the corresponding English journals of Environmental Science and Pollution Research. If the article is accepted for publication, the copyright of English articles will be transferred to Environmental Science and Pollution Research. The author declares that his contribution is original, and that he has full rights to receive this grant. The author requests and assumes responsibility for publishing this material on behalf of any and all co-authors. Copyright transfer covers the exclusive right to copy and distribute articles, including printed matter, translation, photo reproduction, microform, electronic form (offline, online) or any other reproduction of similar nature.

\section{Availability of data and materials}

The authors confirm that all data underlying the findings are fully available without restriction. Data can be obtained after submitting a request to the corresponding/first author.

\section{Competing Interests}

The authors declare no competing financial interest.

\section{Funding}

The authors extend their acknowledgement to the research component of the Sichuan social science base major project "Eco-geochemical evaluation of Chongqing metropolitan economic circle" (Grant number GITR20050101) and Sichuan Science 
and Technology Support Program "Soil Heavy Metal Pollution and Ecological Risk Prediction in Hilly Area of Central Sichuan" (Grant number 2014SZ0068) for supporting the development of this work. The funding body had no role in the design of the study or collection, analysis, and interpretation of data or in writing the manuscript.

\section{Authors Contributions}

Wende Chen—Research concept and design; writing the article

Kun Zhu-Collection and assembly of data; critical revision of the article; writing the article

Yankun Cai-Collection and assembly of data; final approval of article

Peihao Peng-Collection and assembly of data; data analysis and interpretation

\section{References:}

Aelion, C. M. and H. T. Davis, et al. (2008). "Metal concentrations in rural topsoil in South Carolina: Potential for human health impact." SCIENCE OF THE TOTAL ENVIRONMENT 402 (2-3): 149-156.

Aelion, C. M. and H. T. Davis, et al. (2008). "Metal concentrations in rural topsoil in South Carolina: Potential for human health impact." SCIENCE OF THE TOTAL ENVIRONMENT 402 (2-3): 149-156.

Aguilera, A. and F. Bautista, et al. (2021). "Heavy metal pollution of street dust in the largest city of Mexico, sources and health risk assessment." Environmental Monitoring and Assessment 193 (4).

Akhter, M. S. and I. M. Madany (1993). "Heavy metals in street and house dust in Bahrain." Water Air Soil Pollut(66).

Almeida, A. and B. Garrod (2018). "A CATREG model of destination choice for a mature Island destination." Journal of Destination Marketing \& Management 8: 32-40.

Amato, F. and M. Pandolfi, et al. (2009). "Spatial and chemical patterns of PM10 in road dust deposited in urban environment." ATMOSPHERIC ENVIRONMENT 43 (9): 1650-1659.

Birke, M. and C. Reimann, et al. (2017). "GEMAS: Cadmium distribution and its sources in agricultural and grazing land soil of Europe Original data versus clr-transformed data." JOURNAL OF GEOCHEMICAL EXPLORATION 173: 13-30.

Chen, X. and M. Guo, et al. (2019). "Characterization and risk assessment of heavy metals in road dust from a developing city with good air quality and from Shanghai, China." Environmental Science and Pollution Research 26 (11): 11387-11398.

Davis, H. T. and C. M. Aelion, et al. (2009). "Identifying natural and anthropogenic sources of metals in urban and rural soils using GIS-based data, PCA, and spatial interpolation." ENVIRONMENTAL POLLUTION 157 (8-9): 2378-2385.

Deng, J. and W. Li, et al. (2020). "Correlation and the concentrations of Pb, Cd, $\mathrm{Hg}$ and As in vegetables and soils of Chongqing, China." ENVIRONMENTAL GEOCHEMISTRY AND HEALTH.

Deng, Y. and C. Chen, et al. (2018). "Investigation on the characteristics of overlying strata caving in the Chengchao Iron Mine, China." ENVIRONMENTAL EARTH SCIENCES 77 (10).

DeRosa, C. T. and H. Choudhury, et al. (1991). "An integrated exposure/pharmacokinetic based approach to the assessment of complex exposures. Lead: a case study." Toxicology and industrial health 7 (4): 231-48.

Ezekwe, I. C. and N. N. Odu, et al. (2012). "Assessing regional groundwater quality and its health implications in the Lokpaukwu, Lekwesi and Ishiagu mining areas of southeastern Nigeria using factor analysis." ENVIRONMENTAL EARTH SCIENCES 67 (4): $971-986$.

Fang, G. and C. Lo, et al. (2011). "Atmospheric Particle Bound Mercury Hg(p) Concentrations and Amounts in Total Suspended Particulates and Dry Deposition at an Industrial and Wetland Sampling Sites in Taiwan." Environmental forensics 12 (3): 200-205.

Fernández, S. and T. Cotos-Yáñez, et al. (2018). "Geographically Weighted Principal Components Analysis to assess diffuse pollution sources of soil heavy metal: Application to rough mountain areas in Northwest Spain." Geoderma 311: 120-129.

Gundacker, C. and K. J. Wittmann, et al. (2009). "Genetic background of lead and mercury metabolism in a group of medical students in Austria." Environmental Research 109 (6): 786-796.

Huseyin, S. and T. Tulay, et al. (2018). "Geochemical mass balance applied to the study of weathering and evolution of soils." INDIAN JOURNAL OF GEO-MARINE SCIENCES 47 (9): 1851-1865.

Ivankovic, N. and M. Kasanin-Grubin, et al. (2010). "POSSIBLE SOURCES OF HEAVY METALS IN URBAN SOILS: EXAMPLE FROM BELGRADE, SERBIA." JOURNAL OF ENVIRONMENTAL PROTECTION AND ECOLOGY 11 (2): 455-464.

Khademi, H. and M. Gabarrón, et al. (2020). "Distribution of metal(loid)s in particle size fraction in urban soil and street dust: influence of population density." Environmental Geochemistry and Health 42 (12): 4341-4354.

Kim, J. A. and J. H. Park, et al. (2016). "Heavy Metal Distribution in Street Dust from Traditional Markets and the Human Health Implications." INTERNATIONAL JOURNAL OF ENVIRONMENTAL RESEARCH AND PUBLIC HEALTH 13 (8).

Kwon, M. J. and J. Y. Lee, et al. (2017). "Spatial distribution, mineralogy, and weathering of heavy metals in soils along zinc-concentrate ground transportation routes: implication for assessing heavy metal sources." ENVIRONMENTAL EARTH SCIENCES 76 (23).

Lax, K. and O. Selinus (2005). "Geochemical mapping at the Geological Survey of Sweden." GEOCHEMISTRY-EXPLORATION ENVIRONMENT ANALYSIS 5 (4): 337-346.

Liu, H. and Y. Zhang, et al. (2021). "Quantitative source apportionment, risk assessment and distribution of heavy metals in agricultural soils from southern Shandong Peninsula of China." Science of The Total Environment 767: 144879.

Liu, S. and J. Jiang, et al. (2018). "Assessment of water-soluble thiourea-formaldehyde (WTF) resin for stabilization/solidification (S/S) of heavy metal contaminated soils." JOURNAL OF HAZARDOUS MATERIALS 346: 167-173.

Ma, Y. and Z. Jia, et al. (2017). "Risk assessment of heavy metals in soil of Tongnan District (Southwest China): evidence from multiple indices with high-spatial-resolution sampling." Environmental Science and Pollution Research 24 (25): 20282-20290.

Mama, C. N. and C. C. Nnaji, et al. (2021). "Environmental burden of unprocessed solid waste handling in Enugu State, Nigeria." Environmental Science and Pollution Research 28 (15): 19439-19457.

Manuel Trujillo-Gonzalez, J. and M. Aurelio Torres-Mora, et al. (2016). "Heavy metal accumulation related to population density in road dust samples taken from urban sites under different land uses." SCIENCE OF THE TOTAL ENVIRONMENT 553: 636-642.

Mirzaei Aminiyan, M. and M. Baalousha, et al. (2018). "The ecological risk, source identification, and pollution assessment of heavy metals in road dust: a case study in Rafsanjan, SE Iran." Environmental Science and Pollution Research 25 (14): 13382-13395.

Moros, J. and M. J. Martinez-Sanchez, et al. (2009). "Testing of the Region of Murcia soils by near infrared diffuse reflectance spectroscopy and 
chemometrics." TALANTA 78 (2): 388-398.

Othman, M. and M. T. Latif (2013). "Dust and Gas Emissions from Small-Scale Peat Combustion." Aerosol and Air Quality Research 13 (3): 1045-1059.

Rahman, M. S. and Y. N. Jolly, et al. (2021). "Sources of toxic elements in indoor dust sample at export processing zone (EPZ) area: Dhaka, Bangladesh; and their impact on human health." Environmental Science and Pollution Research.

Sabet Aghlidi, P. and M. Cheraghi, et al. (2020). "Analysis, spatial distribution and ecological risk assessment of arsenic and some heavy metals of agricultural soils, case study: South of Iran." JOURNAL OF ENVIRONMENTAL HEALTH SCIENCE AND ENGINEERING 18 (2): 665-676.

Shao, S. and B. Hu, et al. (2021). "Comprehensive source identification and apportionment analysis of five heavy metals in soils in Wenzhou City, China." Environmental Geochemistry and Health.

Siddiqui, Z. and P. S. Khillare, et al. (2020). "Pollution characteristics and human health risk from trace metals in roadside soil and road dust around major urban parks in Delhi city." Air Quality, Atmosphere \& Health 13 (11): 1271-1286.

Wang, L. and X. Li, et al. (2020). "Green remediation of $\mathrm{Cd}$ and $\mathrm{Hg}$ contaminated soil using humic acid modified montmorillonite: Immobilization performance under accelerated ageing conditions." JOURNAL OF HAZARDOUS MATERIALS 387.

$\mathrm{Xu}, \mathrm{T}$. and L. Wang, et al. (2018). "Heavy metal pollution of oil-based drill cuttings at a shale gas drilling field in Chongqing, China: A human health risk assessment for the workers." ECOTOXICOLOGY AND ENVIRONMENTAL SAFETY 165: 160-163.

$\mathrm{Xu}$, X. and X. Zhang, et al. (2021). "Spatial Distribution and Source Apportionment of Agricultural Soil Heavy Metals in a Rapidly Developing Area in East China." Bulletin of Environmental Contamination and Toxicology 106 (1): 33-39.

Yan, M. and X. Ding, et al. (2021). "Potential ecological and health risk assessment of different kiwifruit orchards in Qianjiang district, Chongqing city, China." ENVIRONMENTAL SCIENCE AND POLLUTION RESEARCH 28 (3): 3088-3105.

Yang, J. and J. Wang, et al. (2020). "Identifying factors that influence soil heavy metals by using categorical regression analysis: A case study in Beijing, China." Frontiers of Environmental Science \& Engineering 14 (3).

Zhang, H. and Y. Huang, et al. (2020). "Pollution level and risk assessment of heavy metals in sewage sludge from eight wastewater treatment plants in Wuhu City, China." Spanish Journal of Agricultural Research 18 (2): e1103. 